\title{
Michał Łuszczuk, Ewolucja ról międzynarodowych w Arktyce, Lublin 2015, s. 343
}

$\mathbf{M}$ onografia pt. Ewolucja ról międzynarodowych $w$ Arktyce Michała Łuszczuka z Uniwersytetu Marii CurieSkłodowskiej w Lublinie stanowi właściwe podsumowanie jego dotychczasowej pracy badawczej. Autor jest wiodącym polskim naukowcem badającym stosunki międzynarodowe w regionie, o szerokim uznaniu na świecie. Jest członkiem licznych międzynarodowych gremiów zrzeszających badaczy przedmiotu, a większość jego dorobku naukowego stanowią prace opublikowane w języku angielskim.

Celem przyświecającym autorowi w tej publikacji jest deskrypcja ewolucji ról międzynarodowych w Arktyce oraz eksplanacja, dlaczego oraz w jaki sposób zmienia się aktywność głównych uczestników stosunków międzynarodowych $\mathrm{w}$ regionie. W tym przypadku mowa jest o państwach arktycznych, które konstytuują warstwę podmiotową pracy oraz pełnią tytułowe role. Są to podstawowe założenia przyjęte przez autora.

Pytania badawcze, jakie stawia, dotyczą uwarunkowań ról międzynarodowych w Arktyce - jak zmieniały się w przyję- tych ramach czasowych, jakie czynniki na nie wpływały i wpływają obecnie oraz jak odnoszą się do szerszego kontekstu międzynarodowego, na poziomie systemowym. Hipotezami weryfikowanymi w toku wywodu są zdania, że to uwarunkowania zewnętrzne powodują zmianę aktywności międzynarodowej państw arktycznych, a owe zmiany mają określoną dynamikę, choć różny charakter. Zmiany ról arktycznych wpływają zaś na zmianę postrzegania i znaczenia regionu. Podstawą teoretyczną pracy jest koncepcja ról międzynarodowych osadzona na gruncie teorii stosunków międzynarodowych. Z przyjętych ram wywodzą się zatem określone stanowiska ontologiczne i epistemologiczne oraz metodologia prowadzonych badań.

W rozdziale pierwszym autor opisuje przyjętą kategorię analityczną, ukazuje jej miejsce w dyscyplinie oraz czyni ustalenia o jej przydatności na gruncie teoretycznym i metodologicznym do badania ewolucji stosunków międzynarodowych w regionie. Rozdział drugi przedstawia Arktykę jako środowisko ról międzyna- 
rodowych. Za wielowymiarową charakterystyką regionu następuje prezentacja go w kontekście historycznym, poprzez nadane konkretnemu okresowi metafory, jak np. „Arktyka jako terytorium podboju”, czy idąc dalej, „Arktyka jako strefa współpracy”. W dalszej części autor przedstawia podmiotowy wymiar stosunków międzynarodowych w regionie, wskazując prócz państw arktycznych na instytucje współpracy, państwa nie-arktyczne oraz aktorów niepaństwowych. Dokładniejsza charakterystyka wszystkich ośmiu państw arktycznych oraz ewolucji ich ról została dokonana w rozdziale trzecim, co stanowi najdłuższą i najważniejszą część pracy. Role arktyczne tych podmiotów zostały opisane w perspektywie historycznej poprzez ich uwarunkowania, koncepcje oraz efektywność. Na koniec, w rozdziale czwartym, role zostały wpisane w szerszy kontekst systemowy stosunków międzynarodowych oraz dokonano prognozy ich ewolucji w następnych latach.

Autor podjął się w pracy trudnego zadania operacjonalizacji koncepcji ról międzynarodowych (ang. international role theory) do badania stosunków międzynarodowych w Arktyce. Jak pokazuje wnikliwa analiza literatury przedmiotu, jest to pierwsze tego typu przedsięwzięcie badawcze, uwzględniając przy tym monografie zagraniczne. Praca nie jest zatem polemiką z innymi w zakresie tego samego tematu. Ukazuje to jej przyczynkowość, czyli wartość dodaną wniesioną do niej. Problematyczną kwestią wydaje się również objęcie analizą całości stosunków międzynarodowych w regionie, gdyż wymaga to wnikliwego badania szeregu czynników, często spoza dziedziny zainteresowania politologii, co w naturalny sposób rodzi problemy przy syntezie wniosków z niej wynikających. Receptą autora na ten problem jest użycie odpowiedniego podejścia teoretyczno-metodologicznego.

Koncepcja ról międzynarodowych jest w oczach niektórych badaczy kategorią analityczną mniej popularną niż jeszcze w latach 80. XX wieku, choć od tego czasu dokonała się jej znacząca ewolucja, związana z rozwojem innych podejść teoretycznych. Autor jest świadomy tego faktu. Niosąc w sobie duży ładunek metodologii badań, koncepcja ról międzynarodowych nie daje się jednoznacznie wpisać w obecne debaty interparadygmatyczne w obrębie dyscypliny, a według poszczególnych kategoryzacji wpisywana jest na styku poziomu systemowego oraz subsystemowego analizy stosunków międzynarodowych. Z tej perspektywy autor stosuje prawidłową kolejność we wnioskowaniu, opisując wpierw wewnętrzne uwarunkowania polityki zagranicznej państw arktycznych, wyrażaną przez nie wolę działania na tym polu, a później - jak to wpływa na poziom regionalny stosunków międzynarodowych. Podstawą koncepcji ról międzynarodowych, z punktu widzenia funkcji nauki, jest eksplanacja stosunków międzynarodowych, rozumianych w tym przypadku jako pole badawcze, co stanowi jednocześnie istotną część monografii. Chodzi również o ich najbardziej możliwe uproszczenie na poziomie systemowym oraz prowadzonej przez poszczególne państwa polityki zagranicznej, co ukazuje tutaj charakter przyjętej w książce metodologii. W omawianej pracy autor wykazuje się dobrą znajomością obranego podejścia teoretycznego, co stanowi kluczową kwestię przy jej operacjonalizacji dla problemu badawczego.

Właściwa dla studiów regionalnych jest również obrana metodologia oraz sposób prowadzonych badań. Autor prowadził je na miejscu w państwach arktycz- 
nych, ze szczególnym uwzględnieniem państw skandynawskich. Badania jakościowe dotyczyły pracy źródłowej w miejscowych bibliotekach, poprzez analizę literatury przedmiotu, dokumentów rządowych i dokumentów instytucji międzynarodowych oraz przeprowadzonych wywiadów pogłębionych z wybranymi badaczami przedmiotu oraz politykami z państw arktycznych, a także spoza nich.

Układ rozdziałów w pracy jest przejrzysty, a wywód prowadzony jest w sposób logiczny, dzięki wyraźnie zarysowanym na początku hipotezom, które w jego toku zostały pozytywnie zweryfikowane. Najważniejsze wyniki przeprowadzonych badań zostały ponadto wpisane $\mathrm{w}$ tabele i wykresy. Śmiałym posunięciem wydaje się przedstawiona na końcu pracy prognoza rozwoju ról międzynarodowych w Arktyce, co stanowi problematyczną sferę zarówno w omawianym polu badawczym, jak i szerzej, w naukach społecznych. Podkreśla to jednak wiedzę i doświadczenie autora w swojej dziedzinie, dzięki czemu możliwe jest formułowanie pewnych sądów o przyszłości.

W literaturze przedmiotu można dostrzec prace, które swoją treścią próbują objąć całość okołobiegunowych stosunków międzynarodowych, jak np. publikacja International Relations and the Arctic: Understanding Policy and Governance, której redaktorami są Robert W. Murray i Anita Dey Nuttall (2014). Jak w powyższym przypadku, często są to prace zbiorowe. Monografia autora wyróżnia się na tle pozostałych zastosowanymi założeniami teoretycznymi i metodologicznymi, które zostały wykorzystano właściwie i zgodnie z przeznaczeniem. Szkoda tylko, że nie została wydana również $\mathrm{w}$ języku angielskim, co umożliwiłoby szerszy dostęp do jej zawartości badaczom zagranicznym.

Ewolucję ról międzynarodowych w Arktyce, zgodnie z założeniami autora, można polecić zarówno rodzimym badaczom stosunków międzynarodowych w Arktyce, którzy mogą przyswoić ich nowatorskie ujęcie, oraz - szerzej - politologom, którzy mogą ją zanalizować przez pryzmat ontologiczno-epistemologiczny i metodologiczny. Książka stanowi zatem dobre źródło wiedzy dla badaczy i studentów niezaznajomionych z tematyką relacji okołobiegunowych, ze względu na jej rozbudowane rozdziały wstępne oraz rzeczową deskrypcję i eksplanację, w myśl ich założeń. 